\title{
XANTHINE OXIDASE INHIBITORY ACTIVITY OF METHANOL EXTRACT FRACTIONS OF VARIOUS INDONESIAN ETHNOPHARMACOLOGICAL PLANTS
}

\section{ADITYA SINDU SAKTI, HARNANDA WIDYASTANTO, ASTRI MAULIDINA, DIAN MITASARI, DIYAH SANTI ERIYANI, ABDUL MUN'IM*}

Department of Pharmacognosy Phytochemistry, Faculty of Pharmacy, Universitas Indonesia, Depok 16424, Indonesia. Email: munim@farmasi.ui.ac.id

Received: 02 October 2019, Revised and Accepted: 24 December 2019

ABSTRACT

Objective: Hyperuricemia involves an increase in serum uric acid levels, resulting in kidney damage, increased mortality, and reduced quality of life. Inhibitors of xanthine oxidase, which catalyzes the last step in uric acid synthesis, are targets for therapeutic intervention.

Methods: An ethnopharmacological approach, screening four native Indonesian herbal medicinal plants with reported activity against hyperuricemia, was used for preliminary studies, fractionating methanolic extracts by solvent partitioning. Fractions were then tested in vitro for xanthine oxidase inhibitory activity, and the most active fraction was then subjected to preliminary phytochemical screening.

Results: The target tissue of the four herbal medicinal plants investigated was Indian bay leaf (Syzygium polyanthum Wight.), God's crown fruit (Phaleria macrocarpa Boerl.), snake fruit peel (Salacca edulis Reinw.), and Job's tears tuber (Cyperus rotundus Linn.). Each sample was extracted by maceration with $80 \%$ methanol. The concentrated extract was then fractionated by the liquid-liquid partition method (1:1 v/v) using n-hexane, ethyl acetate, butanol, and methanol sequentially as solvents. The results revealed that the ethyl acetate fraction was the most active fraction. S. polyanthum leaf and C. rotundus tuber showed the greatest potential in inhibiting xanthine oxidase, with half-maximal inhibitory concentrations of 18.43 and $10.50 \mu \mathrm{g} / \mathrm{ml}$, respectively. Enzyme kinetics analysis shows that each plant fraction works as a competitive inhibitor of xanthine oxidase.

Conclusion: Preliminary screening identified the ethyl acetate fractions of two native Indonesian herbal medicinal plants as showing potential for anti-hyperuricemia activity.

Keywords: Ethnopharmacological, Hyperuricemia, Phytochemical screening, Xanthine oxidase.

(c) 2020 The Authors. Published by Innovare Academic Sciences Pvt Ltd. This is an open access article under the CC BY license (http://creativecommons. org/licenses/by/4. 0/) DOI: http://dx.doi.org/10.22159/ijap.2020.v12s1.FF004

\section{INTRODUCTION}

Hyperuricemia is a pathological condition where uric acid levels in the blood are elevated above the normal range [1]. This condition can persist for a long time without any symptoms. During the asymptomatic period, the deposition of uric acid crystals may lead to chronic pain, causing joint damage in some patients [2]. In young patients, hyperuricemia stimulates oxidative stress, inflammation, and inflammatory response as feedback from the oxidative stress triggered by the high uric acid concentration itself [3]. Acute and chronic inflammation due to crystal deposition in joints and soft tissues is a consequence that occurs when hyperuricemia is not immediately treated [4].

Uric acid is the final product of the catabolism of purine nucleotides. There are two main sources of purines. The first one is endogenous, originating from the synthesis of purines de novo and their subsequent breakdown as part of nucleic acid turnover. Purines can also come from exogenous sources, such as food [5]. Many enzymes are involved in the purine catabolism pathway, where eventually adenine will be converted into hypoxanthine and guanine will be converted to xanthine. Hypoxanthine will be oxidized to xanthine, and finally, xanthine is oxidized again by xanthine oxidase to form uric acid [1]. Xanthine oxidase inhibitors, such as purine analogs, are used to treat hyperuricemia and gout, and there is pharmaceutical interest in the exploitation of natural plant xanthine oxidase inhibitors such as inositols and flavonoids.

An ethnopharmacological approach investigates the basis of the traditional use by native people of natural materials, such as plants, animals, fungi, microorganisms, and minerals, in treating specific medical conditions [6]. Many modern pharmaceuticals originated from traditional medicine and ethnopharmacology [7], either directly, using natural compounds as drugs, or as lead compounds in drug development.

Tubers of rumput teki or Job's tears (Cyperus rotundus Linn.) have been widely used in Indonesia as a traditional medicine to treat dysentery and painful joints, and as a diuretic [8], whereas leaves of the Indian bay leaf (Syzygium polyanthum Wight.) are used as a traditional medicine to treat muscle pain and uric acid accumulation [9]; a water extract of $S$. polyanthum has also been reported to significantly reduce blood plasma uric acid concentrations [10]. God's crown (Phaleria macrocarpa Berl.) is a native plant from Papua, Indonesia, the fruit of which has been used traditionally for a number of medicinal uses, including the treatment of kidney disease [11]. Snake fruit (Salacca edulis Reinw.) peel is traditionally used to reduce uric acid levels and has been shown to reduce uric acid levels in the Wistar rat model [12]. The aim of the current study was to investigate the potential of these ethnopharmacological plants to reduce uric acid levels through inhibition of the xanthine oxidase pathway.

\section{MATERIALS AND METHODS}

\section{Plant material}

Indian bay leaf (S. polyanthum) and God's crown fruit (P. macrocarpa) were obtained from a local market in West Java, Indonesia. Fruit of snake fruit (S. edulis) was obtained from Magelang, Indonesia and tubers of Job's tears (C. rotundus) were obtained from Bogor, Indonesia. Each of the samples was authenticated by Herbarium Bogoriense. The samples were cleaned, impurities were removed, and each sample was 
then dried at $60^{\circ} \mathrm{C}$. The dried samples were powdered and stored in desiccator cabinets at room temperature until further analysis.

\section{Preparation of extract}

The preparation of extract was performed based on Yanti et al. with a number of modifications [13]. Each sample powder (1 kg) was extracted using the maceration method with $80 \%(\mathrm{v} / \mathrm{v})$ methanol as the solvent. The powder was allowed to extract in the methanol for approximately $24 \mathrm{~h}$, before being filtered. The solid was re-extracted 3 more times, and the filtrates obtained were combined and the pooled filtrate was then evaporated to dryness using a rotary vacuum evaporator at $40^{\circ} \mathrm{C}$. This crude extract was stored at $-20^{\circ} \mathrm{C}$ before use for further analysis.

\section{Procedure of fractionation}

The extract obtained was dissolved in $200 \mathrm{ml} \mathrm{dH}_{2} \mathrm{O}$, and then fractionated by liquid-liquid partitioning $(1: 1 \mathrm{v} / \mathrm{v})$, using a sequence of solvents, from non-polar to polar, namely, n-hexane, ethyl acetate, butanol, and methanol. Partitioning was carried out 3 times in a separating funnel, each for $1 \mathrm{~h}$. The fractions from one extract were combined and dried with a rotary vacuum evaporator to produce a concentrated extract fraction [14].

\section{Determination of xanthine oxidase inhibitory activity}

The determination of xanthine oxidase inhibitory activity was performed based on Ahmad et al. with a number of modifications [15]. A sub-sample $(10 \mathrm{mg}$ ) of an extract or extract fraction was dissolved in $4 \mathrm{gtt}$ of dimethyl sulfoxide (DMSO), before adding $\mathrm{CO}_{2}$ free $\mathrm{dH}_{2} \mathrm{O}$ to obtain a $1.0 \mu \mathrm{g} / \mathrm{ml}$ stock solution. The stock solution was then diluted to a $0.1 \mu \mathrm{g} / \mathrm{mL}$ working solution. One milliliter of working solution was added to $2.9 \mathrm{ml} 0.05 \mathrm{M}$ phosphate buffer $\mathrm{pH} 7.5,2 \mathrm{ml} 0.2 \mathrm{mM}$ xanthine, and $1 \mathrm{ml}$ of $1 \mathrm{~N} \mathrm{HCl}$, the reaction mixture then being shaken vigorously until homogeneous. The mixture was incubated for $10 \mathrm{~min}$ at $25^{\circ} \mathrm{C}$, before adding $0.1 \mathrm{ml} 0.1 \mathrm{unit} / \mathrm{ml}$ xanthine oxidase and $1 \mathrm{ml} 2 \mathrm{~N} \mathrm{HCl}$. The final mixture was incubated at $25^{\circ} \mathrm{C}$ for $30 \mathrm{~min}$ and absorbance $\left(A_{290}\right)$ was measured after the incubation was terminated. The control used DMSO without the extract or fraction sub-sample. The percentage inhibition was calculated from the equation below:

$$
\text { Inhibition }(\%)=1-\frac{\text { Sample absorbance }}{\text { Control absorbance }} \times 100
$$

Extracts or fractions that achieved an inhibitory effect of more than $50 \%$ were tested again using the same method at concentrations of $5,10,20,40$, or $80 \mu \mathrm{g} / \mathrm{mL}$ to determine the half-maximal inhibitory concentration $\left(\mathrm{IC}_{50}\right)$ value by regression.

\section{Preliminary phytochemical screening}

In this study, preliminary phytochemical screening was carried out to determine the presence/absence of phytochemicals of a particular group in the extract fractions that had the greatest inhibitory activity against xanthine oxidase. Phytochemical screening was performed for a number of chemical groups, namely, alkaloids, glycosides, saponins, flavonoids, tannins, and terpenes.

\section{Identification of alkaloids}

A sample (500 mg) of extract fraction was dissolved in $10 \mathrm{ml}$ of $0.2 \mathrm{~N}$ aqueous $\mathrm{HCl}$, then heated for $2 \mathrm{~min}$. The mixture was filtered, and the filtrate was used as the test solution (TS). Each $1 \mathrm{ml}$ aliquot of TS was reacted with $2 \mathrm{ml}$ of various test reagents. Bouchardat's reagent resulted in a dark-brown precipitate in the presence of alkaloids, whereas Mayer's reagent resulted in a white precipitate for a positive reaction, and Dragendorff's test showed a reddish-orange precipitate as a positive result [16].

\section{Identification of glycosides}

A sample (300 mg) was dissolved in $15 \mathrm{ml}$ of $10 \% \mathrm{HCl}$, then filtered. The filtrate obtained was washed with ether 3 times, and the resulting filtrate was evaporated to dryness at $40^{\circ} \mathrm{C}$. To the filtrate were then added $2 \mathrm{ml}$ methanol, this solution being used as the TS. An aliquot ( $1 \mathrm{ml})$ of TS was evaporated to dryness and dissolved in $20 \mathrm{ml}$ concentrated acetic acid and $1 \mathrm{ml}$ concentrated sulfuric acid. A green or blue color indicated the presence of glycosides. Identification with Molisch's test was performed by dissolving the evaporated TS in $2 \mathrm{ml} \mathrm{dH}_{2} \mathrm{O}$ and $5 \mathrm{ml}$ Molisch's reagent. To the solution, $2 \mathrm{ml}$ sulfuric acid was added carefully. The formation of a reddish-purple colored ring at the junction between the two layers indicated the presence of glycosides [17].

\section{Identification of saponins}

The identification of saponin compounds was carried out by the simple froth test method. A sample (500 mg) of the extract fraction was put in a test tube, to which was added $10 \mathrm{ml}$ of hot distilled water, and the tube was shaken vigorously for $10 \mathrm{~s}$. The formation of foam that lasted for at least $10 \mathrm{~min}$ and that did not disappear with the addition of $1 \mathrm{ml}$ of $2 \mathrm{~N}$ $\mathrm{HCl}$, indicated the presence of saponin compounds [17].

\section{Identification of flavonoids}

Flavonoid identification was performed using Shinoda test methods. A sample $(500 \mathrm{mg}$ ) of the fraction was dissolved in $2 \mathrm{ml}$ of ethanol, to which was added $500 \mathrm{mg}$ of $\mathrm{Zn}$ powder and $2 \mathrm{ml} 2 \mathrm{~N} \mathrm{HCl}$, following which the reaction mixture was allowed to stand for $1 \mathrm{~min}$. Following the addition of $10 \mathrm{ml}$ concentrated $\mathrm{HCl}$, the appearance of a red color after 2-5 min incubation indicated the presence of flavonoids. The same method was used with $100 \mathrm{mg}$ of $\mathrm{Mg}$ powder replacing the $\mathrm{Zn}$ powder to identify the presence of flavones, chalcones, and aurones. The appearance of a yellow to orange color indicated the presence of compounds of flavones, chalcones, or aurones [16].

\section{Identification of tannins}

A sample $(200 \mathrm{mg}$ ) of the fraction was dissolved in $5 \mathrm{ml}$ of hot distilled water, to which was added $10 \% \mathrm{NaCl}$, and the solution was filtered. The filtrate (TS) was then tested using the gelatin test and $\mathrm{FeCl}_{3}$ test methods. To $1 \mathrm{ml}$ of TS was added $3 \mathrm{ml} \mathrm{10 \%} \mathrm{gelatin} \mathrm{solution,} \mathrm{with} \mathrm{the} \mathrm{formation} \mathrm{of}$ a white precipitate, indicating the presence of tannins. The ferric chloride test was performed by added $2 \mathrm{ml} \mathrm{3 \%} \mathrm{FeCl}_{3}$ to $1 \mathrm{ml}$ of TS, with a change in coloration to violet-green indicating that the sample contained tannins [17].

\section{Identification of terpenes}

A sample (200 $\mathrm{mg}$ ) of the fraction was dissolved in a solution of concentrated acetic acid:concentrated sulfuric acid $(2: 1 \mathrm{v} / \mathrm{v})$, at which point the formation of a greenish-red or violet-blue color indicated the presence of terpenes. To confirm the result, the procedure continued by spraying a sample with a solution of $p$-anisaldehyde in concentrated sulfuric acid, when dark-blue, green, red, or brown fluorescence at $366 \mathrm{~nm}$ ultraviolet light indicated the presence of terpenes [17].

\section{RESULTS AND DISCUSSION}

\section{Xanthine oxidase inhibitory activity}

The data obtained showed that the ethyl acetate fraction from each sample showed the highest inhibitory activity against xanthine

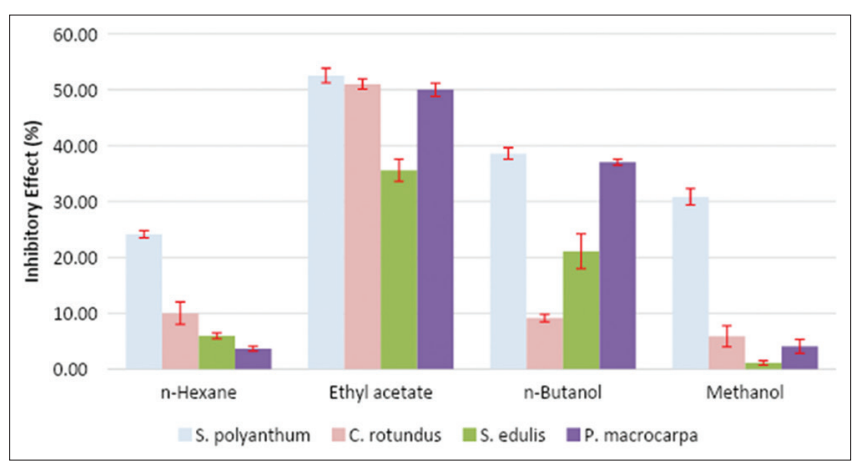

Fig. 1: Xanthine oxidase inhibitory activity from solvent partitioning fractions of a methanolic extract of $S$. polyanthum, C. rotundus, $S$. edulis, and $P$. macrocarpa. Each sample is expressed as the mean \pm standard error of the mean of two independent experiments 
Table 1: Natural deep eutectic solvents combinations and mole ratios used in this study

\begin{tabular}{lllllll}
\hline Samples & \multicolumn{3}{l}{ Phytochemical presence } & & & \\
\cline { 2 - 7 } & Alkaloid & Glycoside & Saponin & Flavonoid & Tannin & Terpene \\
\hline Syzygium polyanthum & + & + & + & + & + & + \\
Cyperus rotundus & - & + & - & + & - & - \\
Salacca edulis & - & + & + & + & + & + \\
Phaleria macrocarpa & - & + & + & + & + \\
\hline
\end{tabular}

$(+)$ present, (-) not detected

oxidase, in a comparison with the other extract fractions (Fig. 1). The ethyl acetate fraction of all four plant crude extracts had the highest mean \pm standard error of the mean inhibitory activity, namely, S. polyanthum $(52.54 \pm 1.29 \%)$, C. rotundus $(51.01 \pm 0.95 \%)$, P. macrocarpa (50.00 $1.16 \%)$, and S. edulis (35.58 $\pm 2.00 \%)$. Interestingly, S. polyanthum exhibited the highest xanthine oxidase inhibitory activity in each of the solvent fractions (Fig. 1). Fractions that exhibited a xanthine oxidase inhibitory effect of greater than $50 \%$ could have their $\mathrm{IC}_{50}$ value determined; this was not possible for $S$. edulis. Analysis showed that $S$. polyanthum had a $\mathrm{IC}_{50}$ of $18.43 \mu \mathrm{g} / \mathrm{ml}$, C. rotundus $10.50 \mu \mathrm{g} / \mathrm{ml}$, and P. macrocarpa $19.23 \mu \mathrm{g} / \mathrm{ml}$, whereas allopurinol, a well-known inhibitor of xanthine oxidase activity exhibited a IC $_{50}$ of $0.067 \mu \mathrm{g} / \mathrm{ml}$, making it more than 100 times more active than the most active plant extract, C. rotundus.

To investigate the kinetics of the xanthine oxidase inhibition by the plant fractions, we also performed the Lineweaver-Burk plot. The results showed the intersection of the straight line from the test with and without the inhibitor at the Y-axis. This is interpreted as all four plant fractions operating a competitive inhibition mechanism against xanthine oxidase. In such a system, there is no change in the $V_{\max }$ value, but there is a change in the value of $K_{m}$ that needs a higher substrate concentration to reach the $K_{m}$ value [18]. The difference between reversible and irreversible inhibition is that reversible inhibitors are easier to dissociate, thus causing shorter inhibition time. Competitive inhibition allows both the inhibitors and the substrates to bind to the same active site of the enzyme, but they cannot occupy the same active site of the enzyme at the same time. Therefore, the inhibitors will compete with the substrate to occupy the active site of the enzyme [19]. Basically, xanthine oxidase is an enzyme with low specificity. Because xanthine oxidase participates in the catabolism of xenobiotics, such as antiblastic and antimetabolic drugs, a xanthine oxidase inhibitor should be used carefully when these drugs are also being taken [20].

\section{Phytochemical screening}

The most active fraction (the ethyl acetate fraction) of each sample extract in terms of xanthine oxidase inhibitory activity was subjected to phytochemical screening to reveal which groups of phytochemical compounds were present. As shown in Table 1, all of the ethyl acetate fractions from the original crude methanolic extract of the four medicinal plants studied contained glycosides and flavonoid compounds.

The S. polyanthum ethyl acetate fraction of the leaf extract contained all of the compounds tested for, namely flavonoids, terpenes, alkaloids, saponins, tannins, and glycosides (Table 1). Recent work showed a number of bioactive compounds in the ethyl acetate fraction of the $S$. polyanthum leaf methanolic extract, including $\alpha$-pinene, linalool, nerolidol, caryophyllene oxide, farnesol, phytol, squalene, $\beta$-tocopherol, $\alpha$-tocopherol, $\beta$-sitosterol, $\alpha$-humulene, neophytadiene, hentriacontane, and octanal [21].

The Abd Rahim et al. study [21] also reported that the ethyl acetate fraction of the $C$. rotundus tuber methanolic extract contained glycoside compounds, which were suspected to be the terpenoid iridoid glycoside groups such as $1 \alpha$-meth-oxy- $3 \beta$-hydroxy- $4 \alpha$ - $\left(3^{\prime}, 4^{\prime}\right.$-dihydroxyphenyl)$1,2,3,4$,-tetra-hydronaphthalin and $1 \alpha, 3 \beta$-dihydroxy- $4 \alpha-\left(3^{\prime}, 4^{\prime}-\right.$ dihydrox-yphenyl)-1,2,3,4,-tetrahydronaphthalin or other rotundus side compounds and their isomers that had been reported by another research team [22], although this tentative identification requires confirmation. The presence of flavonoid compounds in the $C$. rotundus fraction, which we identified, was also reported by Kilani et al. [23]. They described that the ethyl acetate fraction of $C$. rotundus contained flavonoid compounds such as afzelechin, catechin, quercetin, and luteolin.

We reported that the ethyl acetate fraction of $S$. edulis contained a number of phytochemical constituents such as glycosides, flavonoids, and tannins (Table 1). Afrianti et al. discovered that the ethyl acetate fraction of $S$. edulis contained a number of phytochemical compounds such as 3-hydroxystigmastan-5(6)-en and pyrolle-2,4-dicarboxylic acid, methyl ester [24], whereas another phytochemical screening study also reported that $S$. edulis contained flavonoids and tannins [24,25]. The positive results for glycosides detected in this current research are expected to be associated with the high sugar content in S. edulis.

Based on Table 1, the phytochemical compounds present in the ethyl acetate fraction of $P$. macrocarpa include glycosides, saponins, flavonoids, tannins, and terpenes. These data are similar to those in an article reviewing data reported by Alara et al. The positive results for glycosides, saponins, and terpenes could have been due to the presence of fevicordin in P. macrocarpa, which is classified as terpenoid. In the form of sugar conjugates, fevicordin would give positive results for glycoside as well as saponin. It was also reported that P. macrocarpa contains flavonoids, tannins, and gallic acid [26].

\section{CONCLUSION}

Various plants used in ethnomedicine have been scientifically proven to have beneficial effects in treating hyperuricemia through a competitive inhibitory mechanism against xanthine oxidase. In the current study, C. rotundus tuber was the herbal medicinal plant with the greatest potential for development as a hyperuricemia treatment by inhibiting xanthine oxidase ( $\left.\mathrm{IC}_{50}=10.50 \mu \mathrm{g} / \mathrm{ml}\right)$.

\section{ACKNOWLEDGMENTS}

This study was supported by the Directorate of Research and Community Engagement Universitas Indonesia through Hibah PITTA 2017. that ares

\section{REFERENCES}

1. Jin M, Yang F, Yang I, Yin Y, Luo JJ, Wang H, et al. Uric acid, hyperuricemia and vascular diseases. Front Biosci (Landmark Ed) 2012;17:656-69.

2. Mandell BF. Clinical manifestations of hyperuricemia and gout. Cleve Clin J Med 2008;75 Suppl 5:S5-8.

3. Zhou Y, Zhao M, Pu Z, Xu G, Li X. Relationship between oxidative stress and inflammation in hyperuricemia: Analysis based on asymptomatic young patients with primary hyperuricemia. Medicine (Baltimore) 2018;97:e13108

4. Ruoff G, Edwards NL. Overview of serum uric acid treatment targets in gout: Why less than $6 \mathrm{mg} / \mathrm{dL}$ ? Postgrad Med 2016;128:706-15.

5. Grassi D, Ferri L, Desideri G, Di Giosia P, Cheli P, Del Pinto R, et al. Chronic hyperuricemia, uric acid deposit and cardiovascular risk. Curr Pharm Des 2013;19:2432-8.

6. Leonti M, Casu L. Traditional medicines and globalization: Current and future perspectives in ethnopharmacology. Front Pharmacol 2013;4:92.

7. Patwardhan B. Ethnopharmacology and drug discovery. 
J Ethnopharmacol 2005;100:50-2.

8. Sivapalan S. Medicinal uses and pharmacological activities of Cyperus rotundus Linn a review. Int J Sci Res Publ 2019;3:1-8.

9. Nahdi M, Kurniawan A. Ethnobotanical study of medicinal plants in karst environment in Gunung Kidul, Yogyakarta, Indonesia. Nusantara Biosci 2019;11:133-41.

10. Darussalam M, Rukmi D. Peran air rebusan daun salam (Syzgium polyanthum) dalam menurunkan kadar Asam Urat. Media Ilmu Kesehatan 2016;5:83-91

11. Hendra R, Ahmad S, Oskoueian E, Sukari A, Shukor MY. Antioxidant, anti-inflammatory and cytotoxicity of Phaleria macrocarpa (Boerl.) scheff fruit. BMC Complement Altern Med 2011;11:110.

12. Priyatno L, Sukandar E, Ibrahim S, Adnyana I. Antihyperuricemic effect of ethanol extract of snakefruit (Salacca edulis Reinw.) var. Bongkok on Wistar male rat. J Food Sci Eng 2012;2:271-6.

13. Yanti A, Radji M, Mun'im A, Suyatna F. Antioxidant effects of methanolic extract of Phaleria macrocarpa (Scheff.) Boerl in fructose 10\%-induced rats. Int J PharmTech Res 2015;8:41-7.

14. Ahmad A, Mun'im A, Elya B. Study of antioxidant activity with reduction of DPPH radical and xanthine oxidase inhibitor of the extract of Ruellia tuberosa Linn. leaf. Int Res J Pharm 2012;3:66-70.

15. Ahmad A, Elya B, Mun'im A. Antioxidant activity and isolation of xanthine oxidase inhibitor from Ruellia tuberosa L. leaves. Pharmacogn J 2017;9:607-10

16. Sakti A, Saputri F, Mun'im A. Microscopic characters, phytochemical screening focus on alkaloid and total phenolic content of Uncaria gambir Roxb. and Uncaria sclerophylla Roxb. leaves. Pharmacogn J 2019;11:119-23.

17. Pratami D, Mun'im A, Sundowo A, Sahlan M. Phytochemical profile and antioxidant activity of propolis ethanolic extract from Tetragonula bee. Pharmacogn J 2017;10:128-35.

18. Ferrier D, Harvey R. Lippincott's Illustrated Reviews: Biochemistry. Vol. 6. Philadelphia, PA: Wolters Kluwer Health; 2014

19. Berg J, Tymoczko J, Stryer L. Biochemistry. Vol. 5. New York: W H Freeman; 2003.

20. Battelli MG, Polito L, Bortolotti M, Bolognesi A. Xanthine oxidoreductase in drug metabolism: Beyond a role as a detoxifying enzyme. Curr Med Chem 2016;23:4027-36.

21. Abd Rahim E, Ismail A, Omar M, Rahmat U, Wan Ahmad W. GCMS analysis of phytochemical compounds in Syzygium polyanthum leaves extracted using ultrasound-assisted method. Pharmacogn J 2017:10:110-9

22. Pirzada AM, Ali HH, Naeem M, Latif M, Bukhari AH, Tanveer A. Cyperus rotundus L.: Traditional uses, phytochemistry, and pharmacological activities. J Ethnopharmacol 2015;174:540-60.

23. Kilani S, Ledauphin J, Bouhlel I, Ben Sghaier M, Boubaker J, Skandrani I, et al. Comparative study of Cyperus rotundus essential oil by a modified GC/MS analysis method. Evaluation of its antioxidant, cytotoxic, and apoptotic effects. Chem Biodivers 2008;5:729-42.

24. Afrianti L, Widjaja W, Suliasih N, Widowati W, Fauziah N, Maesaroh M, et al. Anticancer activity of 3-hydroxystigmastan- 5(6)-en ( $\beta$-sitosterol) compound from Salacca edulis Reinw variety Bongkok in MCF-7 and T47D cell lines. J Adv Agric Technol 2015;2:129-33.

25. Siddiqui M, Saleh M, Mediani A, Ismail N, Ahmed Q, So'ad S, et al. Salacca zalacca: A short review of the palm botany, pharmacological uses and phytochemistry. Asian Pac J Trop Med 2018;11:6450-2.

26. Alara OR, Alara JA, Olalere OA. Review on Phaleria macrocarpa pharmacological and phytochemical properties. Drug Des 2016;5:1-5. 